\title{
Hexavalent Chromium Uptake from Aqueous Solutions using Raw Biomass of the Invasive Brown Seaweed Sargassum muticum from the Moroccan Shorelines: Kinetics and Isotherms
}

\author{
Samir El Atouani, PhD student \\ Soufiane Tahiri, Professor \\ Abdeltif Reani, Professor \\ Fouad Bentiss, Professor \\ Mohammed El Krati, Professor \\ Abdelaziz Sahibed-dine, Professor \\ Abdenbi Schamel, Professor \\ Abdellatif Aarfane, PhD \\ Brahim Sabour, Professor
}

Faculty of Sciences, University Chouaïb Doukkali, El Jadida, Morocco

doi: 10.19044/esj.2016.v12n30p243 URL:http://dx.doi.org/10.19044/esj.2016.v12n30p243

\begin{abstract}
Raw biomass of the invasive Japanese brown seaweed Sargassum muticum, recently introduced to the Atlantic coast of Morocco, has been applied for the removal of hexavalent chromium $\mathrm{Cr}(\mathrm{VI})$ from aqueous solutions. Various parameters such as biomass dose, initial $\mathrm{pH}$, contact time and initial $\mathrm{Cr}(\mathrm{VI})$ concentration were studied to reveal their effects on the biosorption process. At optimum values of the above mentioned parameters, total removal of $\mathrm{Cr}(\mathrm{VI})$ can be achieved within $10 \mathrm{~min}$ at $\mathrm{pH}$ 2, adsorbent dose of $0.5 \mathrm{~g} / 100 \mathrm{~mL}$ for initial chromium ions concentration of $50 \mathrm{mg} / \mathrm{L}$. $\mathrm{Cr}(\mathrm{VI})$ biosorption follows pseudo second-order kinetics. Adsorption isotherms were determined at room temperature and the experimental data were modelled with the Langmuir, Freundlich and Temkin isotherm equations. The isotherm data were found to be well fitted by linear Langmuir equation. The maximum sorption capacity calculated from Langmuir isotherm was estimated to be about $143 \mathrm{mg}$ per gram of dry biosorbent. Thus, the biomass used in this study can be considered a promising and valuable natural adsorbent for the treatment of aqueous solution containing toxic hexavalent chromium ions.
\end{abstract}


Keywords: Sargassum muticum; Seaweeds, Morocco, Biosorption, Hexavalent chromium.

\section{Introduction}

Environmental pollution by metal ions due to the rapid industrialization and technological advances is one of the most significant problems concern in many countries. Several industrial wastewaters contain considerable amount of heavy metals that are recognized as dangerous contaminants because of their high toxicity and bioaccumulation in plant, animal and human. Chromium attracted wide attention of environmentalists as one of the most toxic heavy metals. This metal and its compounds are widely used in many industrial applications including electroplating, chromate manufacturing, alloy reparation industries, metal cleaning and processing, leather tanning, and wood preservation (Joel, 1997). According to the World Health Organization (WHO) drinking water guidelines, the maximum allowable limit for total chromium is $0.05 \mathrm{mg} / \mathrm{L}$ (World Health Organization, 2004). It can exist in several chemical forms, but only two of them, trivalent $\mathrm{Cr}(\mathrm{III})$ and hexavalent $\mathrm{Cr}(\mathrm{VI})$, are stable enough to occur in the environment. Removal of $\mathrm{Cr}(\mathrm{VI})$ from wastewater before disposal is essential because it has been considered that this form is more hazardous to public health due to its both mutagenic and carcinogenic properties (Costa, 2003).

Traditional techniques for removing $\mathrm{Cr}(\mathrm{VI})$ include precipitation (Kurniawan et al., 2006), ion exchange (Rengaraj et al. 2001), membrane separation (i.e. ultrafiltration and reverse osmosis) (Kozlowski and Walkowiak, 2002), reduction and electrochemical reduction (Martinez and Rodriguez, 2007). However these techniques can be ineffective or extremely expensive, especially when the metals are dissolved in large volumes of solution at relatively low concentrations and may also lead to secondary environmental problems from waste disposal (Pehlivan and Arslan, 2007). Therefore, the development of an alternative technology must be considered.

Biosorption to biological materials has been proposed as a potential alternative. Recently, it has gained important credibility because of its ecofriendly nature, high performance and low cost. Basically, it can be based on the following mechanisms such as physical adsorption (electrostatic attraction, Vander-Waal attraction forces) and/or chemical adsorption (covalent binding between negative charge of cell surface and cationic ions) (Vijayaraghavan and Yun, 2008). Innovative approaches using various biomaterials such as bacteria, microalgae, fungi, seaweeds, agricultural byproducts and industrial bio-wastes as an adsorbents for $\mathrm{Cr}(\mathrm{VI})$ removal have been widely reported (Nourbakhsh et al., 1994; Yun at al., 2001; Subbaiah et al., 2008). As far as our knowledge concerns, metal biosorption 
capacity of algal biomass is comparable to chemical sorbents. This is due to the presence of polysaccharides, proteins or lipid on the surface of their cell walls wearing functional groups such as amino, hydroxyl, carboxyl, and sulfate, which act as binding sites for metals (Crist et al., 1981; Davis et al., 2003). Among the various forms of algae, brown algal biomass has been proved the higher metal removal capacities due to higher alginate and fucoidan contents (Sharma and Gupta, 2002).

In this context, the abundantly biomass of the invasive Japanese brown seaweed Sargassum muticum harvested from the Atlantic coast of Morocco was tested as biosorbent for Cr(VI) removal from aqueous solutions. This seaweed, recently introduced to the Moroccan shorelines is recognized priority pest species with a high potential for negative ecological and socioeconomic impacts (Sabour et al., 2013). Consequently, it could offers promising bioresource for industrial applications while controlling the biological invasion and preserving autochthonous species. The effect on $\mathrm{Cr}(\mathrm{VI})$ remediation of various operational conditions such as, $\mathrm{pH}$, adsorbent mass, contact time and initial concentration of chromium was investigated. In addition, applicability of adsorption isotherms and kinetic models was studied in order to better understand the biosorption process.

\section{Materials and methods}

\section{Sampling and preparation of algal biomass}

The brown seaweed Sargassum muticum was collected at low tide in May 2014 from El Jadida coast on the Atlantic of Morocco (Figure 1).

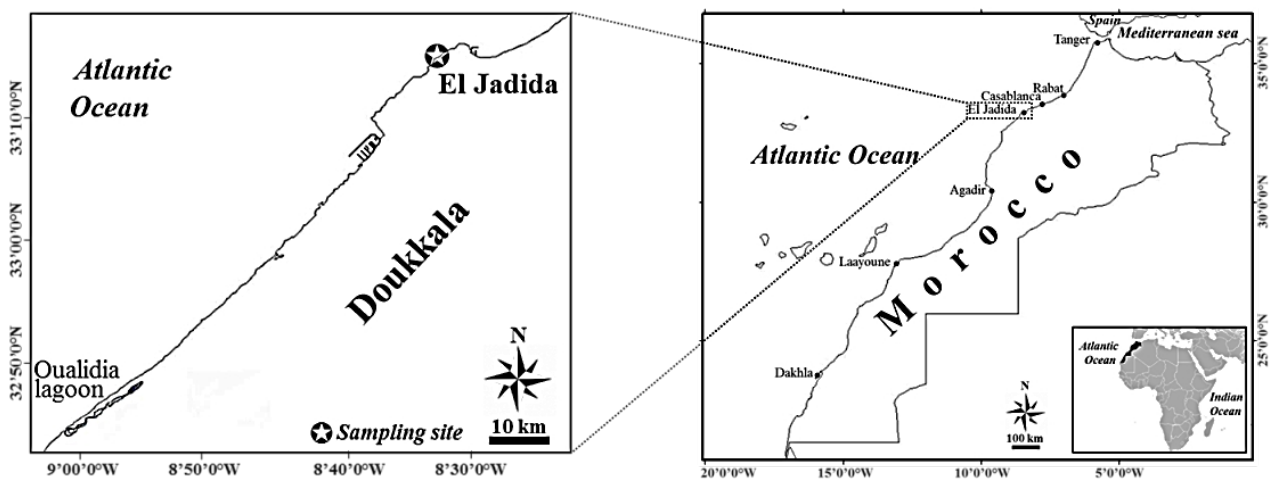

Figure 1. Sampling site ( $\mathbf{0}$ ) of the studied Sargassum muticum biomass.

The collected biomass was thoroughly rinsed with tap water to remove soil and dust. It was dried at room temperature for four days and then at $40^{\circ} \mathrm{C}$ in ventilated oven $24 \mathrm{~h}$. After that, the material was crushed into powder and sieved in order to recover particles with an average size of 0.5 mm. 


\section{Characterization of biosorbent}

The point or $\mathrm{pH}$ of zero charge $\left(\mathrm{pH}_{\mathrm{ZPC}}\right)$, which describes the condition when the electrical charge density on a surface is zero, was determined as described in literature (Mall et al., 2006): $50 \mathrm{~mL}$ of 0.1 molar $\mathrm{M} \mathrm{KNO}_{3}$ was introduced into Erlenmeyer flasks and then the $\mathrm{pH}$ was adjusted to the required value ranging from 1 to 12 by adding $0.1 \mathrm{M} \mathrm{NaOH}$ or $0.1 \mathrm{M} \mathrm{HCl}$ solutions. One gram of dried biomass was added and shaken for 24h. After that, the final $\mathrm{pH}$ of the solution was measured and the point of zero charge was determined by plotting the initial and final $\mathrm{pH}$. To give a qualitative analysis of the main chemical groups present on the cell wall of biomass before and after chromium sorption, FT-IR analysis (Thermo Scientific Nicolet Impact 400D FT-IR Spectrometer) in solid phase was conducted. The infrared spectra were recorded over the wave number range $4000-400 \mathrm{~cm}^{-1}$ in an attenuated total reflectance (ATR) mode and analyzed with the OMNIC 7.1 software.

\section{Preparation and analysis of metal solution}

A stock solution of $\mathrm{Cr}(\mathrm{VI})$ (1.0 g/L) was prepared by dissolving potassium dichromate $\left(\mathrm{K}_{2} \mathrm{Cr}_{2} \mathrm{O}_{7}\right)$ in distilled water. It was then diluted to prepare solutions with desired concentrations ranging from 50 to $800 \mathrm{mg} / \mathrm{L}$. The initial $\mathrm{pH}$ of chromium solutions was adjusted by adding $\mathrm{NaOH} 1 \mathrm{M}$ or $\mathrm{HCl} 1 \mathrm{M}$. All batch experiments were carried out at room temperature $\left(25 \pm 2^{\circ} \mathrm{C}\right)$. The concentration of $\mathrm{Cr}(\mathrm{VI})$ was measured using the spectrophotometric method based on the reaction between chromate ions and 1,5-diphenylcarbazide (DPC) in acidic medium which leads to the formation of a red-violet colored complex (Gilcreas et al., 1965). After 15 min, the absorbance measurements at $540 \mathrm{~nm}$ were performed by JENWAY 6300 UV-Vis spectrophotometer.

To confirm if $\mathrm{Cr}(\mathrm{VI})$ ions were adsorbed onto the raw biomass or reduced to trivalent form $\mathrm{Cr}(\mathrm{III})$, the total residual chromium was determined at different $\mathrm{pH}$ solutions using an UNICAM 929 model flame atomic absorption spectrophotometer. Trivalent chromium $\mathrm{Cr}$ (III) concentration was then obtained from the difference between the total chromium and $\operatorname{Cr}(\mathrm{VI})$ concentrations.

\section{Metal adsorption experiments}

Batch biosorption experiments were performed in 250 Erlenmeyer flasks stirred in a magnetic stirrer (at $250 \mathrm{rpm}$ ) at room temperature $\left(25 \pm 2^{\circ} \mathrm{C}\right)$. In order to investigate the interaction between $\mathrm{Cr}(\mathrm{VI})$ and biomass, the effects of solution $\mathrm{pH}$ (range 1.0-12.0), solid-liquid ratio dose (0.1-1 g/0.1L), contact time (0-60 min) and initial Cr(VI) ions concentration (50-800 mg/L) on the biosorption rate and capacity were studied. To 
determine biosorption isotherms, the biomass (5 g/L) was suspended in chromium solution at various concentrations ranging from 50 to $800 \mathrm{mg} / \mathrm{L}$. The kinetic experiments were carried out using $\mathrm{Cr}(\mathrm{VI})$ solution at $50 \mathrm{mg} / \mathrm{L}$ and samples were taken at different time intervals. After centrifugation at $4500 \mathrm{rpm}$ for $15 \mathrm{~min}$, the supernatant was analyzed for residual metal ion concentration. The amount of $\mathrm{Cr}$ (VI) ions adsorbed per unit mass of the adsorbent at equilibrium conditions Qe (mg/g) was obtained using the following expression:

$$
\mathrm{Q}_{\mathrm{e}}=\frac{\left(\mathrm{C}_{0}-\mathrm{C}_{\mathrm{e}}\right) \mathrm{V}}{\mathrm{m}}
$$

Where, $\mathrm{C}_{0}$ and $\mathrm{C}_{\mathrm{e}}(\mathrm{mg} / \mathrm{L})$ are respectively the initial and equilibrium concentrations of chromium solution, $\mathrm{V}$ are the volume of solution (L), and $\mathrm{m}$ the mass of algae (g). The biosorption efficiency (\%) was determined using the following expression:

$$
\mathrm{R}(\%)=\frac{\left(\mathrm{C}_{0}-\mathrm{C}_{\mathrm{e}}\right)}{\mathrm{C}_{0}} \times 100
$$

\section{Results and discussion}

\section{Point of zero charge $\mathrm{pH}_{\mathrm{ZPC}}$}

The difference between the initial and final $\mathrm{pH}$ value $\left(\Delta \mathrm{pH}=\mathrm{pH}_{\mathrm{i}}\right.$ $\mathrm{pH}_{\mathrm{f}}$ ) was plotted against $\mathrm{pH}_{\mathrm{i}}$ (Figure 2). The intersection point with the abscissa $(\Delta \mathrm{pH}=0)$ corresponds to the point of zero charge values $\left(\mathrm{pH}_{\mathrm{ZPC}}\right)$ (Faria et al., 2004). The $\mathrm{pH}_{\mathrm{ZPC}}$ of the biomass (Figure 2) was found at $\mathrm{pH}$ 5.5. Below this $\mathrm{pH}$ value, the surface charge of the biosorbent is positive and above $\mathrm{pH} 5.5$ the biosorbent surface would have a net negative charge.

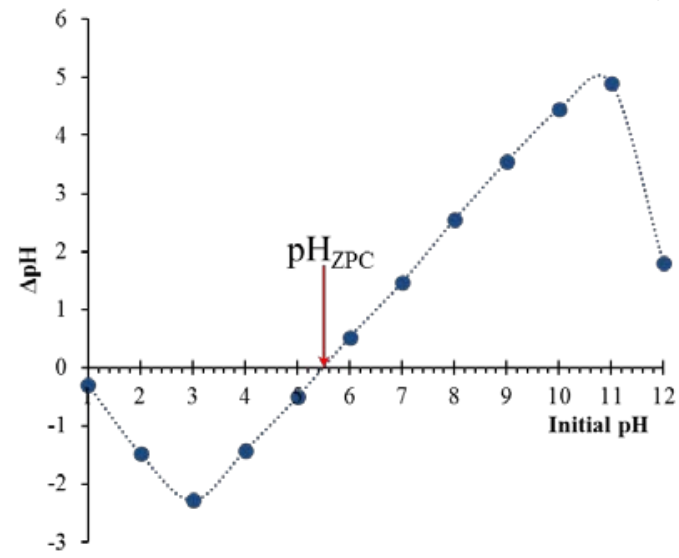

Figure 2. Point of zero charge of Sargassum muticum biomass.

\section{FTIR analysis}

The FTIR spectra of unloaded Sargassum muticum raw biomass and $\mathrm{Cr}(\mathrm{VI})$ loaded biomass were used to highlight some functional groups which 
are responsible of metal ions adsorption (Figure 3). The broad band around $3300 \mathrm{~cm}^{-1}$ is characteristic of $-\mathrm{OH}$ and $-\mathrm{NH}_{2}$ stretching of surface hydroxyl and amino groups while the band observed at $2930 \mathrm{~cm}^{-1}$ is assignable to aliphatic $\mathrm{C}-\mathrm{H}$ stretching vibration $\mathrm{CH}, \mathrm{CH}_{2}$ and $\mathrm{CH}_{3}$ (Tarley and Arruda, 2004). According to Yang and Chen (2008), the new peak which appears around $1725 \mathrm{~cm}^{-1}$ after contacting with $\mathrm{K}_{2} \mathrm{Cr}_{2} \mathrm{O}_{7}$ solution assigned to the formation of $\mathrm{C}=\mathrm{O}$ groups. The peak around $1640 \mathrm{~cm}^{-1}$ in both spectra is arising from the carboxylate salt $\mathrm{COO}-\mathrm{Cations}\left(\mathrm{Na}^{+}, \mathrm{Ca}^{+}, \mathrm{K}^{+}, \mathrm{Mg}^{+}\right)$that may naturally exist in brown algal biomasses. The band at $1025-1035 \mathrm{~cm}^{-1}$ assigned to $\mathrm{C}-\mathrm{O}$ stretching of alcoholic groups involved in the metal binding. $\mathrm{C}-\mathrm{O}$ groups may be found in different environments in algal polysaccharide units and could be attributed particularly to alginate and fucoidan in the case of Sargassum muticum. The band located at $950 \mathrm{~cm}^{-1}$ assigned to the $\mathrm{C}-\mathrm{O}$ stretching vibration of uronic acid residues (Chandía et al., 2004; El Atouani et al., 2016). The absorption peak around $885 \mathrm{~cm}^{-1}$ may correspond to the $\mathrm{S}=\mathrm{O}$ bond, indicating the existence of the sulfonate group that is often found in the seaweed biomass (Fourest and Volesky, 1996). As conclusion, when the biomass was loaded with chromium ions, some peaks disappear or change in intensities confirming the participation of various functional groups in the metal uptake

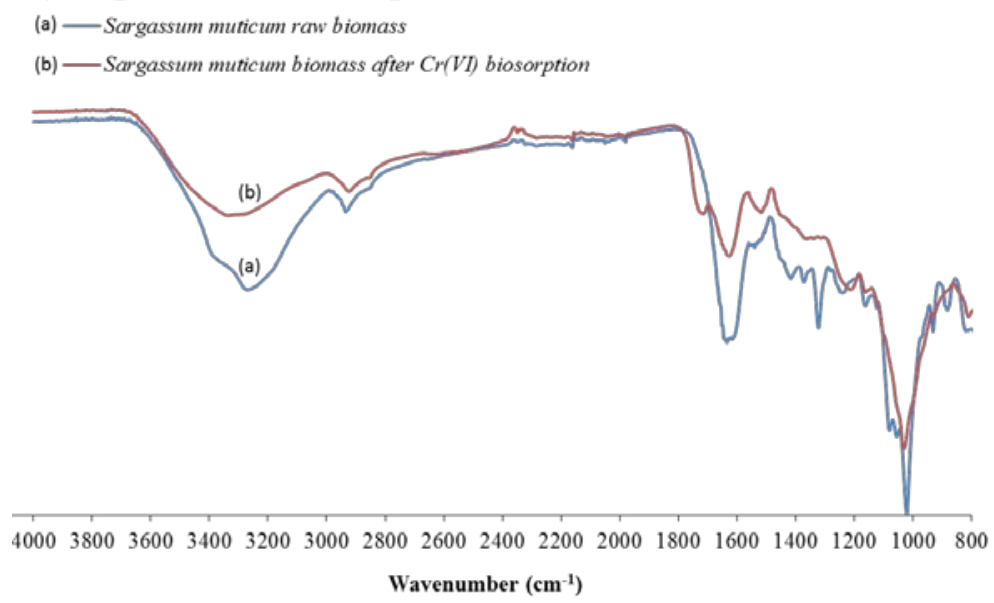

Figure 3. FTIR spectra of Sargassum muticum biomass before (a) and after biosorption process (b).

\section{Effect of pH on biosorption capacity}

Several studies on heavy metal ions indicated that solution $\mathrm{pH}$ is an important parameter affecting biosorption process (Crist et al., 1981; Gokhale et al., 2008) because it affects the biosorbent surface properties and the ionic forms of metal in the solution. To find the optimal $\mathrm{pH}$ for the best biosorption of $\mathrm{Cr}(\mathrm{VI})$ ions by the biomass of Sargassum muticum in aqueous medium, experiments were conducted at various initial $\mathrm{pH}$ values ranging 
from 1 to 9. The effect of $\mathrm{pH}$ was studied at room temperature $\left(25 \pm 2^{\circ} \mathrm{C}\right)$ by agitating $1 \mathrm{~g}$ of biosorbent for $4 \mathrm{~h}$ in $100 \mathrm{~mL}$ of $\mathrm{Cr}(\mathrm{VI})$ solution at $50 \mathrm{mg} / \mathrm{L}$. The evolution of chromium removal efficiency as a function of initial $\mathrm{pH}$ is given in Figure 4. The highest uptake values were found at more acidic $\mathrm{pH} 1$ -2 and the removal of chromium declines significantly with further increase until $\mathrm{pH}$ 9. At lower $\mathrm{pH}$ values, the predominant chromium form is $\mathrm{HCrO}_{4}^{-}$, which shifts gradually to other forms; $\mathrm{CrO}_{4}{ }^{2-}$ and $\mathrm{Cr}_{2} \mathrm{O}_{7}{ }^{2-}$ by increasing $\mathrm{pH}$ solution. The decrease in the adsorption of $\mathrm{Cr}(\mathrm{VI})$ at high $\mathrm{pH}$ values may be due to the formation of soluble hydroxyl complexes involved in the decrease in electrostatic attraction force between the sorbent and sorbate anions $\left(\mathrm{CrO}_{4}{ }^{2-}\right.$ and $\left.\mathrm{Cr}_{2} \mathrm{O}_{7}{ }^{2-}\right)$ (Dong et al., 201). In addition, the surface charge on dried biomass became negative with an increase in $\mathrm{pH}$, resulting in a more Coulomb repulsion of these anions species (Mohan et al., 2011). The cell surface of Sargassum muticum biosorbent consists mainly of polysaccharides, especially alginates which were found to have a better ability to complex heavy metals (Davis et al., 2003).

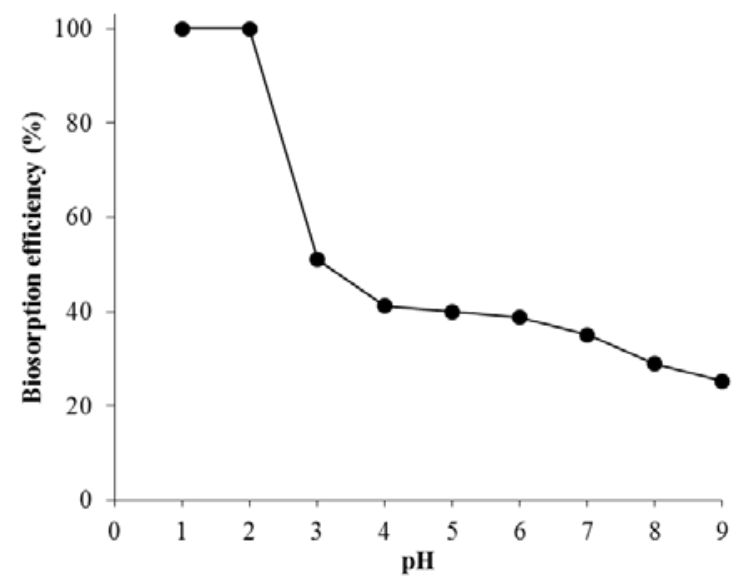

Figure 4. Effect of initial solution $\mathrm{pH}$ on $\mathrm{Cr}$ (VI) biosorption efficiency. Sargassum muticum Biomass dose: $1 \mathrm{~g} / 100 \mathrm{~mL}$, initial $\mathrm{Cr}(\mathrm{VI})$ concentration: $50 \mathrm{mg} / \mathrm{L}$, contact time: 4 h, agitation speed $250 \mathrm{rpm}$.

\section{Effect of biosorbent dose}

The biosorbent dose is another important factor; its effect on the uptake of $\mathrm{Cr}$ (VI) from the aqueous solutions was investigated by varying the amount of dried biomass from 0.0125 to $1 \mathrm{~g}$ per $100 \mathrm{~mL}$ of chromium solution (50 mg/L) at $\mathrm{pH} 2$ (Figure 5). The biosorption efficiency was rapidly improved from about $81 \%$ to $100 \%$, when the biosorbent dose was increased from $0.0125 \mathrm{~g}$ to $0.5 \mathrm{~g} / \mathrm{mL}$ of chromium solution. After that no significant change was observed at dose higher than $10 \mathrm{~g} / \mathrm{L}$. This trend could be explained as a consequence of partial aggregation of biomass at higher biomass concentration, which results in the decrease in effective surface area 
and adsorbate/adsorbent ratio. Similar behavior for the effect of adsorbent dose on sorptive uptake of chromium has been reported by Zhang et al, 2010 using algal bloom residue. The sharp increase in biosorption rate by Sargassum muticum observed at higher adsorbent dosage indicated the accessibility of a larger number of sorption surface sites to uptake chromium ions. The biomass of Sargassum muticum used as raw material in this study contain available biopolymers such as alginates and some sulfated polysaccharides, which are important components in its cell walls (El Atouani et al., 2016). Several studies reported that alginates have a high performance in the uptake sorption of metal ions (Fourest and Volesky, 1996; Sheng et al., 2004).

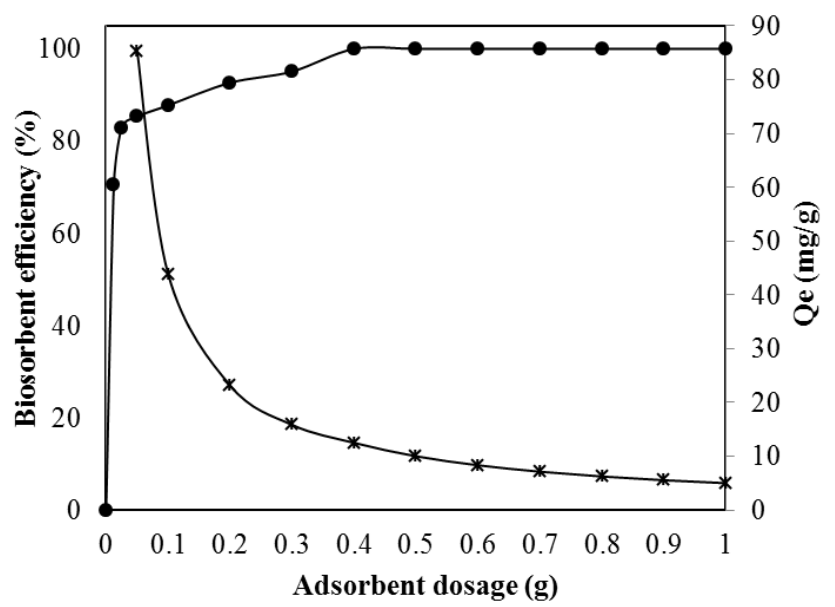

Figure 5. Effect of biomass dosage on the efficiency and capacity of biosorption. Initial $\mathrm{pH}$ :

2, initial $\mathrm{Cr}(\mathrm{VI})$ concentration: $50 \mathrm{mg} / \mathrm{L}$, contact time: 4 h, agitation speed: $250 \mathrm{rpm}$.

\section{Contact time}

The contact time was evaluated as one of the most important factors affecting the biosorption efficiency. The sorptive uptake of $\mathrm{Cr}(\mathrm{VI})$ by Sargassum muticum biomass was studied at the optimum conditions for different contact times (Figure 6). The metal sorption rate is high during the two first minutes and decreases gradually till saturation levels were reached at equilibrium in about $10 \mathrm{~min}$. The initial speed phase might be explained by large number of adsorption sites of the biomaterial (Kousha et al., 2012) and it may involve physical adsorption or ion exchange at cell surface and the subsequent slower phase may involve other mechanisms such as complexation, micro-precipitation or saturation of binding sites (Gupta and Rastogi, 2009). 


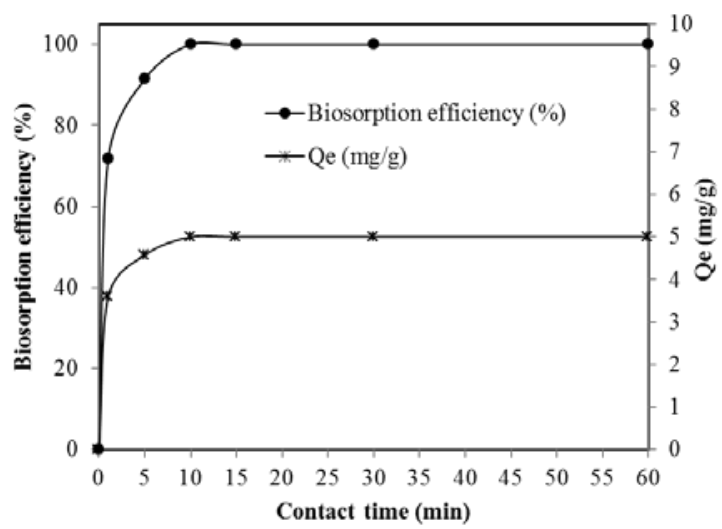

Figure 6: Effect of contact time on the efficiency and capacity of biosorption. Initial solution pH: 2, biosorbent dose: $0.5 \mathrm{~g} / 100 \mathrm{~mL}$, initial metal concentration: $50 \mathrm{mg} / \mathrm{L}$, agitation speed:

\section{Effet of initial Cr (VI) concentration} $250 \mathrm{rpm}$.

The removal of metal ions was evaluated for different initial concentrations of $\mathrm{Cr}(\mathrm{VI})$ ranging from 50 to $800 \mathrm{mg} / \mathrm{L}$. Experiments were carried out at room temperature $\left(25 \pm 2^{\circ} \mathrm{C}\right)$ with the optimum biosorbent dosage $(1 \mathrm{~g} / \mathrm{L})$ at $\mathrm{pH} 2.0$ using an agitation speed of $250 \mathrm{rpm}$. The mixtures were agitated for a contact time of 90 min which is considered more than sufficient to reach equilibrium. Higher concentrations of metal ion play an important role in determination of the maximum adsorption capacity of the adsorbents (Mohanty et al., 2006). As shown in figure 7, chromium biosorption efficiency was gradually decreased from $93.88 \%$ to $81 \%$ with the increment of the initial $\mathrm{Cr}(\mathrm{VI})$ concentration from $100 \mathrm{mg} / \mathrm{L}$ to 800 $\mathrm{mg} / \mathrm{L}$. However, the biosorption capacity $(\mathrm{mg} / \mathrm{g}$ ) increased by increasing initial $\mathrm{Cr}(\mathrm{VI})$ concentration. At the beginning, the sorptive uptake rate was higher due to number of active binding sites, which would have become saturated above a certain concentration providing a dominant driving force to overcome mass transfer resistance of metal ion between the aqueous and solid phases (Weber and Chakraborti, 1974; Onyancha et al., 2008). Another reason for the increased biosorption capacity can be explained by the fact that increasing the initial metal concentration increases the probability of contact between chromium ions and biosorbent. 


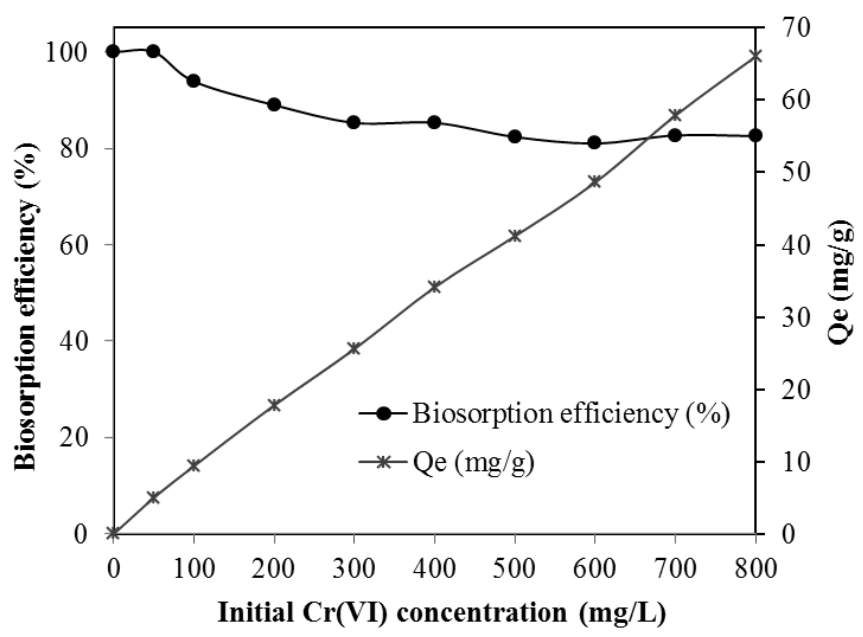

Figure 7. Effect of initial concentration of $\mathrm{Cr}(\mathrm{VI})$ on efficiency and capacity of biosorption. Initial pH: 2, biosorbent dose: $0.5 \mathrm{~g} / 100 \mathrm{~mL}$, contact time: $90 \mathrm{~min}$, agitation speed $250 \mathrm{rpm}$.

\section{Kinetic and isotherm models}

\section{Kinetic studies}

In this study, pseudo-first order and pseudo-second-order models were applied to kinetic data. The integral form of pseudo-first order kinetic model can be presented by the following equation:

$$
\log \left(Q_{e}-Q_{t}\right)=\log Q_{e}-\frac{K_{1} \cdot t}{2.303} \text { (Eq. 3) }
$$

Where $\mathrm{Q}_{e}$ and $\mathrm{Q}_{\mathrm{t}}(\mathrm{mg} / \mathrm{g})$ are the amounts of chromium ions sorbed at equilibrium (mg/g) and $\mathrm{t}(\mathrm{min})$, respectively, and $\mathrm{K}_{1}$ is the rate constant of the equation $\left(\mathrm{min}^{-1}\right)$. The biosorption rate constants $\left(\mathrm{K}_{1}\right)$ can be determined experimentally by plotting $\log \left(\mathrm{Q}_{\mathrm{e}}-\mathrm{Q}_{\mathrm{t}}\right)$ versus $\mathrm{t}$ (Figure 8).

The plot line of $\log \left(Q_{e}-Q_{t}\right)$ versus $t$ (Figure 8) for the pseudo firstorder kinetic model is not well aligned with the experimental data, showing a $\mathrm{R}^{2}$ value of 0.881 (Table 1 ). In addition, the experimental values of $\mathrm{Q}_{e, \exp }$ are not in good agreement with the theoretical values calculated $\left(\mathrm{Q}_{\mathrm{e} 1, \mathrm{cal}}\right)$ from the equation 3. On the other hand, the pseudo first-order kinetic model is not suitable for the complete data range of contact time and can only be applied for preliminary stage of biosorption. 


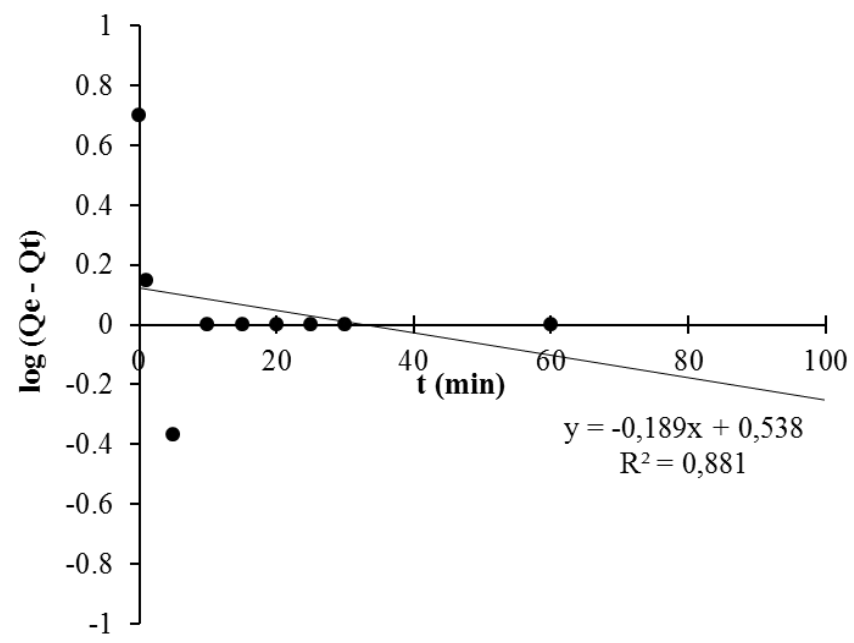

Figure 8: Plot line of the pseudo-first-order equation for the biosorption of $\mathrm{Cr}(\mathrm{VI})$ by Sargassum muticum biomass. Biosorbent dose: $0.5 \mathrm{~g} / 100 \mathrm{~mL}, \mathrm{Cr}(\mathrm{VI})$ concentration: 50 mg/L, stirring speed: $250 \mathrm{rpm}$, temperature $25 \pm 2^{\circ} \mathrm{C}, \mathrm{pH}: 2$.

Experimental data were also treated by the pseudo-second-order kinetic model which is given as follows (Lagergren, 1898):

$$
\frac{t}{Q_{t}}=\left(\frac{1}{Q_{e}}\right) t+\frac{1}{K_{2} Q_{e}^{2}} \quad \text { (Eq. 4) }
$$

Where $t$ is the time $(\min ), Q_{t}$ is the uptake capacity at a given time $t$ (mg.g $\left.{ }^{-1}\right), Q_{e}$ is the equilibrium constant of sorbate ion on surface of the biosorbent (mg.g ${ }^{-1}$ ), and $K_{2}$ is the equilibrium rate constant of pseudo-

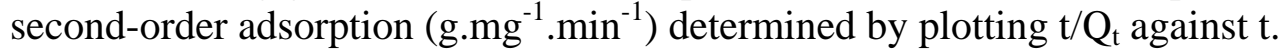

The calculated model parameter values are listed in Table 1 . The obtained results showed that the pseudo-second-order kinetic has correlation coefficients $\left(\mathrm{R}^{2}=1\right)$ higher than that of the pseudo-first-order kinetic model $\left(\mathrm{R}^{2}=0.881\right)$, which mean that pseudo-second-order provides the best fit for biosorption process (Figure 9).

This model is more likely to predict kinetic behavior of biosorption with chemical sorption being the rate-controlling step (Lagergren, 1898). As can be seen in Table 1, the $\mathrm{Q}_{\mathrm{e}, \mathrm{cal}}$ values for the second-order model are more close to $\mathrm{Q}_{\mathrm{e}, \exp }$ values in comparison to first-order values. These results are in agreement with literature (Sari et al., 2008; Koutahzadeha et al., 2013). 


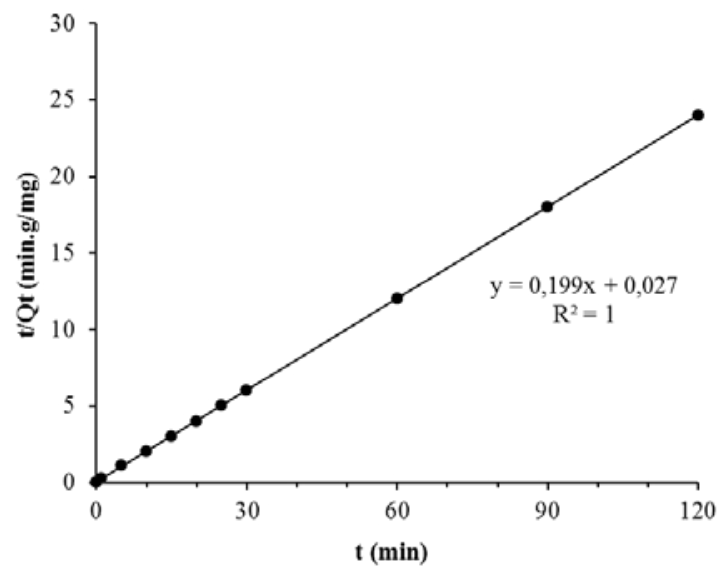

Figure 9. Plot line of the pseudo-second-order equation for the biosorption of $\mathrm{Cr}(\mathrm{VI})$ by Sargassum muticum biomass. Biosorbent dose: $0.5 \mathrm{~g} / 100 \mathrm{~mL}, \mathrm{Cr}(\mathrm{VI})$ concentration: 50 mg/L, stirring speed: $250 \mathrm{rpm}$, temperature $25 \pm 2^{\circ} \mathrm{C}, \mathrm{pH}: 2$.

Table 1. Kinetic parameters for the biosorption of hexavalent chromium onto Sargassum muticum biomass.

\begin{tabular}{|c|c|c|c|c|c|c|c|}
\hline \multicolumn{4}{|c|}{ Pseudo-first-order } & \multicolumn{3}{|c|}{ Pseudo-second-order } & \multirow[b]{2}{*}{$\mathrm{R}^{2}$} \\
\hline $\begin{array}{l}\mathrm{K}_{1} \\
\left(\min ^{-1}\right)\end{array}$ & $\begin{array}{l}\mathrm{Q}_{\mathrm{e}} \text { (exp) } \\
(\mathrm{mg} / \mathrm{g})\end{array}$ & $\begin{array}{l}\mathrm{Q}_{\mathrm{e}(\mathrm{cal})} \\
\text { (mg/g) }\end{array}$ & $\mathrm{R}^{2}$ & $\begin{array}{l}\mathrm{K}_{2} \\
\left(\mathrm{mg} \mathrm{g}^{-1} \cdot \mathrm{min}^{-1}\right)\end{array}$ & $\begin{array}{l}\mathrm{Q}_{\mathrm{e}(\exp )} \\
(\mathrm{mg} / \mathrm{g})\end{array}$ & $\begin{array}{l}\text { Qe (cal) } \\
\text { (mg/g) }\end{array}$ & \\
\hline 0.435 & 5 & 3.451 & 0.881 & 1.466 & 5 & 5.025 & 1 \\
\hline
\end{tabular}

\section{Adsorption isotherms}

Adsorption isotherms are the mathematical models which were characterized by certain constants, whose values express the surface properties and affinity of the biomass. The experiments were carried out with initial chromium concentrations ranging from 50 to $800 \mathrm{mg} / \mathrm{L}$, the other parameters were kept constant. In this work, three sorption isotherm models have been tested to fit experimental data namely Langmuir, Freundlich and Temkin equations.

Langmuir isotherm (Langmuir, 1916) assumes monolayer sorption onto a surface containing a finite number of sorption sites of uniform strategies of sorption with no transmigration of sorbate in the plane of surface (Lagergren, 1898). This isotherm is often offered in the form of the following equation:

$$
\frac{1}{\mathrm{Q}_{\mathrm{e}}}=\frac{1}{\mathrm{~b} \cdot \mathrm{Q}_{\mathrm{m}} \cdot \mathrm{C}_{\mathrm{e}}}+\frac{1}{\mathrm{Q}_{\mathrm{m}}}
$$

Where, $C_{e}$ is the equilibrium concentration in $m g / L, Q_{m}$ is the maximum biosorption capacity in $\mathrm{mg} / \mathrm{g}, \mathrm{Q}_{\mathrm{e}}$ is the amount of chromium sorbed at equilibrium (mg/g) and $\mathrm{b}$ is the Langmuir biosorption constant which indicates the strength or affinity of the sorbent for the solute (Holan et al., 1993). 
The Langmuir biosorption parameters were determined from the linear plot $1 / Q_{e}$ versus $1 / C_{e}$ (Figure 10 ). The correlation coefficient $\left(R^{2}\right)$ was found to be 0.980 , suggesting that the sorption of metal ions by Sargassum muticum was taken place at the functional groups/binding sites on the surface of the algal biomass which may be due to homogenous distribution of active sites on the biomaterial surface, since the Langmuir equation assumes that the surface is homogenous. From the slope of Langmuir isotherm linear equation, the $\mathrm{b}$ value was $5.368 \times 10^{-3} \mathrm{~L} / \mathrm{mg}$. The maximum adsorption $\mathrm{Q}_{\mathrm{m}}$ was $142.86 \mathrm{mg}$ of $\mathrm{Cr}(\mathrm{VI}) / \mathrm{g}$. In order to reveal the biosorption performance of dried biomass for chromium uptake, biosorption capacity $\mathrm{Q}_{\mathrm{m}}$ value was compared with that of various biosorbents originated from different algal species (Table 2). As it can be seen, compared to some seaweeds, Sargassum muticum raw biomass has a high sorption capacity. Thus, it can be considered as efficient and low cost adsorbent for $\mathrm{Cr}(\mathrm{VI})$ removal.

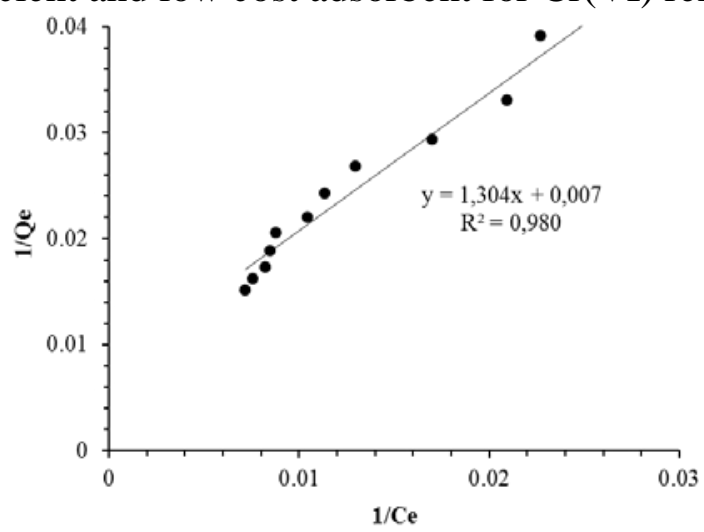

Figure 10. Langmuir isotherm for Cr(VI) biosorption by Sargassum muticum biomass. Biosorbent dose: $0.5 \mathrm{~g} / 100 \mathrm{~mL}$, stirring speed: $250 \mathrm{rpm}$, temperature $25 \pm 2^{\circ} \mathrm{C}, \mathrm{pH}: 2$.

Table 2. Cr(VI) Biosorption capacities of Sargassum muticum biomass compared to some brown seaweeds.

\begin{tabular}{lllll}
\hline Brown seaweed species & $\begin{array}{l}\text { Qm } \\
\text { (mg/g) }\end{array}$ & $\mathbf{p H}$ & $\begin{array}{l}\text { Dose } \\
\text { (g/L) }\end{array}$ & References \\
\hline Cystoseira indica & 43.38 & 1 & 2 & Koutahzadeha et al., 2013 \\
Dictyota cervicornis & 36.32 & 1 & 2 & Koutahzadeha et al., 2013 \\
Dictyopteris polypodioides & 21.78 & 1 & 10 & Belattmania et al., 2015 \\
Fucus spiralis & 5.4 & 2 & 2 & Murphy et al., 2008 \\
Fucus vesiculosuis & 42.7 & 2 & 2 & Murphy et al., 2008 \\
Laminaria japonica & 59.3 & 1 & 4 & Wang et al., 2008 \\
Nizamuddina zanardini & 32.72 & 1 & 2 & Koutahzadeha et al., 2013 \\
Padina australis & 37.82 & 1 & 2 & Koutahzadeha et al., 2013 \\
Sargassum glaucescens & 47.62 & 1 & 2 & Koutahzadeha et al., 2013 \\
Stoechospermum marginatum & 32.63 & 1 & 2 & Koutahzadeha et al., 2013 \\
Sargassum muticum & $\mathbf{1 4 2 . 8 6}$ & $\mathbf{2}$ & $\mathbf{5}$ & This study \\
\hline
\end{tabular}


The essential characteristic of Langmuir isotherm can be explained in terms of a dimensionless separation factor, $\mathrm{R}_{\mathrm{L}}$ (Kiran et al., 2007):

$$
\mathrm{R}_{\mathrm{L}}=\frac{1}{1+\mathrm{b} \cdot \mathrm{C}_{0}}
$$

Where $\mathrm{b}$ is the Langmuir constant related to the apparent energy of sorption and $\mathrm{C}_{0}$ is the initial metal concentration in $\mathrm{mg} / \mathrm{L}$. According to the literature (Kadirvelu et al., 2001; Hameed et al., 2009), $\mathrm{R}_{\mathrm{L}}$ indicates the type of isotherm to be reversible $\left(R_{L}=0\right)$, favorable $\left(0<R_{L}<1\right)$, linear $\left(R_{L}=1\right)$, or unfavorable $\left(R_{L}>1\right)$. From the experimental results (not presented), the values of $R_{L}(0.1-0.4)$ for all initial concentrations of $\operatorname{Cr}(\mathrm{VI})$ (up to 800 $\mathrm{mg} / \mathrm{L}$ ) indicate the favorable biosorption process of $\mathrm{Cr}(\mathrm{VI})$ onto dried biomass. The sorption was more favorable at higher initial concentrations which are in agreement with the results reported in other research works (Hameed et al., 2009; Javadian et al., 2013).

Freundlich model was chosen to estimate the sorption intensity of the sorbate on the sorbent surface. This model assumes a heterogeneous adsorbed surface and active sites with different energy. Freundlich expression is given by the following equation (Freundlich, 1906):

$$
\ln \mathrm{Q}_{\mathrm{e}}=\ln \mathrm{K}_{\mathrm{F}}+\frac{1}{\mathrm{n}} \ln \mathrm{C}_{\mathrm{e}}
$$

Where $\mathrm{K}_{\mathrm{f}}$ is a constant related to the Freundlich adsorption capacity $(\mathrm{L} / \mathrm{mg})$ and $1 / \mathrm{n}$ is an empirical parameter relating the biosorption intensity, which varies with the heterogeneity of the material. Figure 11 shows the Freundlich isotherms obtained by fitting equilibrium data to the equation 7 . The values of $K_{f}$ and $1 / n$ were found to be 0.541 and 0.745 , respectively. The $1 / \mathrm{n}$ values were between 0 and 1 , indicating that uptake sorptive was favorable at the studied conditions. The magnitude of both $\mathrm{K}_{\mathrm{f}}$ and $\mathrm{n}$ show easily uptake of chromium ions from aqueous solution and a high adsorption capacity (Ucun et al., 2002).

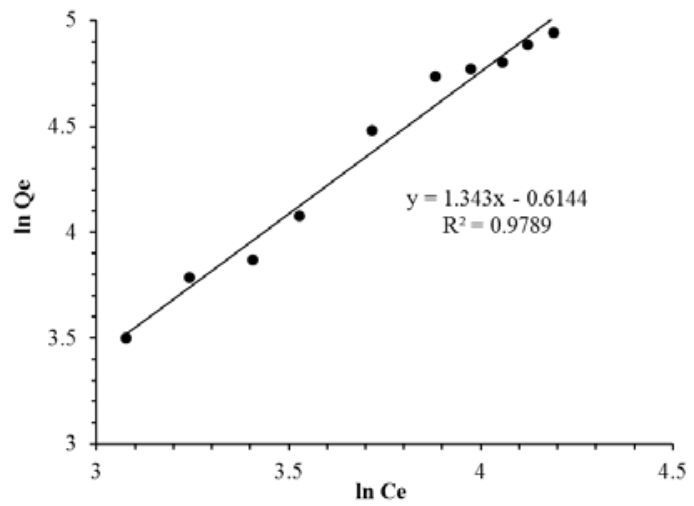

Figure 11. Freundlich isotherm for Cr(VI) biosorption by Sargassum muticum biomass. Biosorbent dose: $0.5 \mathrm{~g} / 100 \mathrm{~mL}$, stirring speed: $250 \mathrm{rpm}$, temperature $25 \pm 2^{\circ} \mathrm{C}, \mathrm{pH}: 2$. 
Furthermore, the obtained experimental data were treated using Temkin isotherm model. The derivation of Tempkin isotherm (Temkin, 1941) assumes that the fall in the heat of sorption is linear rather than logarithmic, as implied in Freundlich equation. Tempkin isotherm has generally been applied in the following form equation (Eq. 8) (Wang et al., 2005):

$$
\mathrm{Q}_{\mathrm{e}}=\frac{\mathrm{RT}}{\mathrm{b}_{\mathrm{T}}} \ln \mathrm{K}_{\mathrm{T}}+\frac{\mathrm{RT}}{\mathrm{b}_{\mathrm{T}}} \ln \mathrm{C}_{\mathrm{e}} \quad \text { (Eq. 8) }
$$

where $\mathrm{K}_{\mathrm{T}}$ is the equilibrium binding constant corresponding to the maximum binding energy, $\mathrm{b}_{\mathrm{T}}$ is the Temkin isotherm constant, $\mathrm{T}$ is the temperature $(\mathrm{K})$, and $\mathrm{R}$ is the ideal gas constant $(8.315 \mathrm{~J} / \mathrm{mol} / \mathrm{K})$. The values of $b_{T}$ and $K_{T}$ were determined from the slope and intercept of the linear plot Qe against $\ln$ Ce (Figure 12). The values of $b_{T}$ and $K_{T}$ were estimated to be $0.08 \mathrm{KJ} / \mathrm{mol}$ and $0.99 \mathrm{~L} / \mathrm{g}$, respectively. The obtained correlation coefficient $\left(\mathrm{R}^{2}\right)$ was 0.93 less than Freundlich and Langmuir isotherms, suggesting that the experimental data didn't fit well the Temkin model. The results indicate also that the surface of Sargassum muticum biomass is heterogeneous in nature and didn't possess equal distribution of binding energies on the available binding sites.

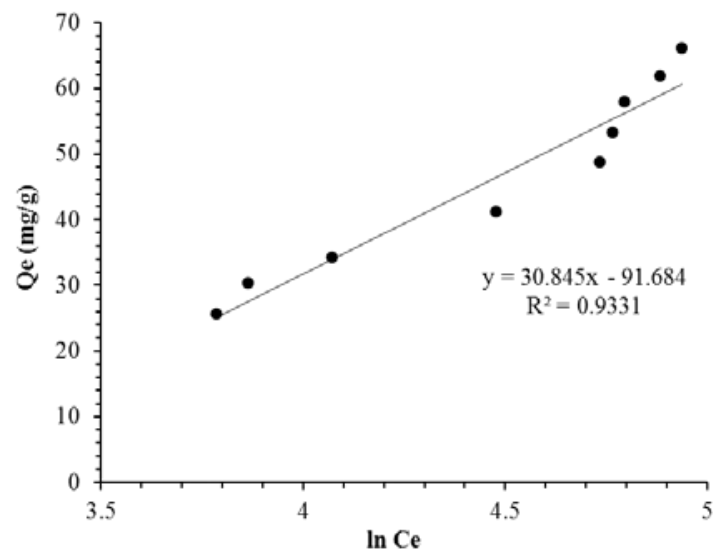

Figure 12. Temkin isotherm for $\mathrm{Cr}(\mathrm{VI})$ biosorption by Sargassum muticum biomass. Biosorbent dose: $0.5 \mathrm{~g} / 100 \mathrm{~mL}$, stirring speed: $250 \mathrm{rpm}$, temperature $25 \pm 2^{\circ} \mathrm{C}, \mathrm{pH}: 2$.

\section{Conclusion}

In this work, the removal of hexavalent chromium from aqueous solution by raw biomass of Sargassum muticum was studied. The results obtained highlight clearly the feasibility of using this natural material as an alternative biosorbent for the uptake of toxic chromium ions. The major findings of this study can be summarized as follow:

The removal of hexavalent chromium from aqueous solutions increased with increasing biosorbent dosage suggesting the dependence of 
the efficiency on the amount of surface sites of the biosorbent. The adsorption process is strongly dependent of the $\mathrm{pH}$ and it is more effective at acid medium ( $\mathrm{pH} 1-2)$. The effect of contact time reveals that the sorption process is extremely rapid with a $\mathrm{Cr}(\mathrm{VI})$ removal efficiency of $100 \%$ within the first ten minutes.

Pseudo-second-order model shows the best fit with the experimental data. The results were furthermore analyzed using three isotherm models: Langmuir, Freundlich and Temkin. The Langmuir $\mathrm{R}_{\mathrm{L}}$ value indicates that the adsorption of chromium $\mathrm{Cr}(\mathrm{VI})$ onto Sargassum muticum biomass is favorable. Furthermore, Freundlich $\mathrm{K}_{\mathrm{f}}$ and $\mathrm{n}$ parameters implies favorable chromium ions uptake and a high adsorption capacity. Nevertheless, the experimental data didn't fit well the Temkin isotherm model compared to Freundlich and Langmuir models.

In conclusion, the use of biomass algae of Sargassum muticum as natural biosorbent for the removal of hexavalent chromium from aqueous solutions is recommended as it is not only economical material but also an effective alternative to conventional methods.

\section{References:}

1. Belattmania, Z., Tahiri, S., Zrid, R., Reani, A., Elatouani, S., Loukili, H., Hassouani, M., El Krati, M., Bentiss, F. \& Sabour, B. (2015). Bioremoval of Hexavalent Chromium from Aqueous Solutions by the Brown Seaweed Dictyopteris polypodioides, Research Journal of Environmental Toxicology, 9, 218-230.

2. Chandía, N. P., Matsuhiro, B., Mejías E. \& Moenne, A. (2004). Alginic acids in Lessonia vadosa: Partial hydrolysis and elicitor properties of the polymannuronic acid fraction, Journal of Applied Phycology, 16, 127-33.

3. Costa M. (2003). Potential hazards of hexavalent chromate in our drinking water, Toxicology and applied pharmacology, 188, 1-5.

4. Crist, H. R., Oberholser, K., Shank, N. \& Nguyen, M. (1981). Nature of bonding between metallic ions and algal cell walls, Environmental Science and Technology, 15, 1212-1217.

5. Davis, T.A., Volesky, B. \& Mucci, A. (2003). A review of the biochemistry of heavy metal biosorption by brown algae, Water Research, 37, 4311-4330.

6. Dong, X., Ma, L. \& Li., Q. Y. (2011). Characteristics and mechanisms of hexavalent chromium removal by biochar from sugar beet tailing, Journal of Hazardous Materials, 190, 909-915.

7. El Atouani, S., Bentiss, F., Reani, A., Zrid, R., Belattmania, Z., Pereira, L., Mortadi, A., Cherkaoui, O., \& Sabour B. (2016). The invasive brown seaweed Sargassum muticum as new resource for 
alginate in Morocco: Spectroscopic and rheological characterization, Phycological Research, 64, 185-193.

8. Faria, P. C. C., Órfão, J. J. M. \& Pereira, M. F. R. (2004). Adsorption of anionic and cationic dyes on activated carbons with different surface chemistries, Water Research, 8, 2043-2052.

9. Fourest, E. \& Volesky, B. (1996). Contribution of sulfonate groups and alginate to heavy metal biosorption by the dry biomass of Sargassum fluitas, Environmental Science and Technology, 30, 277282.

10. Freundlich, H.M.F. (1906). Uber die adsorption in losungen, Journal of Physical Chemistry, 57, 385-470.

11. Gilcreas, F.W., Tarars, M. J. \& Ingols, R. S. (1965). Standard Methods for the Examination of Water and Wastewater. $12^{\text {th }}$ ed. American Public Health Association, New York.

12. Gokhale, S.V., Jyoti, K.K. \& Lele, S.S. (2008). Kinetic and equilibrium modeling of chromium(VI) biosorption on fresh and spent Spirulina platensis/Chlorella vulgaris biomass, Bioresource Technology, 99, 3600-3608.

13. Gupta, V.K. \& Rastogi, A. (2009). Biosorption of hexavalent chromium by raw and acid-treated green alga Oedogonium hatei from aqueous solutions, Journal of Hazardous Materials, 163, 396402.

14. Hameed, B. H., Salman, J. M. \& Ahmad, A. L. (2009). Adsorption isotherm and kinetic modeling of 2,4-D pesticide on activated carbon derived from date stones, Journal of Hazardous Materials, 163, 121126.

15. Holan, Z.R., Volesky, B. \& Prasetyo, I. (1993), Biosorption of cadmium by biomass of marine algae, Biotechnology and Bioengineering, 41, 819-825.

16. Javadian, H. Ahmadi, M. Ghiasvand, M. Kahrizi, S. Katal, R. (2013). Removal of $\mathrm{Cr}(\mathrm{VI})$ by modified brown algae Sargassum bevanom from aqueous solution and industrial wastewater, Journal of the Taiwan Institute of Chemical Engineers, 44, 977-989.

17. Joel, B. (1997). Occurrences, uses, and properties of chromium, Regulatory Toxicology and Pharmacology, 26, 3-7.

18. Kadirvelu, K., Thamaraiselvi, K. \& Namasivayam, C. (2001). Removal of heavy metals from industrial wastewaters by adsorption onto activated carbon prepared from an agricultural solid waste, Bioresource Technology, 76, 63-65.

19. Kiran, B., Kaushik, A., Kaushik, C.P. J. Hazard. Mater. (2007). Biosorption of $\mathrm{Cr}(\mathrm{VI})$ by native isolate of Lyngbya putealis (HH-15) 
in the presence of salts, Journal of Hazardous Materials, 141, 662667.

20. Kousha, M., Daneshvar, E., Sohrabi, M.S., Koutahzadeh, N. \& Khataee, A. R. (2012). Optimization of C.I. acid black 1 biosorption by Cystoseira indica and Gracilaria persica biomasses from aqueous solutions, International Biodeterioration and Biodegradation, 67, 56-63.

21. Koutahzadeha, N., Daneshvarb, E., Koushab, M. \& Sohrabia, M.S. (2013). Bhatnagarc A. Biosorption of hexavalent chromium from aqueous solution by six brown macroalgae, Desalination and Water Treatment, 51, 6021-6030.

22. Kozlowski, C.A. \& Walkowiak, W. (2002). Removal of chromium (VI) from aqueous solutions by polymer inclusion membranes, Water Research, 36, 19, 4870-4876.

23. Kurniawan, T.A., Chan, G.Y.S., Lo, W. \& Ba-bel, S. (2006). Physico-chemical treatment techniques for wastewater laden with heavy metals, Chemical Engineering Journal, 118, 83-98.

24. Lagergren, S. (1898), Zur theorie der sogenannten adsorption geloster stoffe, Kungliga Svenska Vetenkapsakademiens, Handlingar, 24, 139.

25. Langmuir, I. (1916). The constitution and fundamental properties of solids and liquids. Part I. Solids, Journal of the American Chemical Society, 38 (11) 2221-2295.

26. Mall, I. D., Shrivastava, V. C., Kumar, G. V. A. \& Mishra, I. M. (2006). Characterization and utilization of mesoporous fertilizer plant waste carbon for adsorptive removal of dyes from aqueous solution, Colloids and Surfaces A: Physicochemical and Engineering Aspects, 278, 175-87.

27. Martinez, S.A. \& Rodriguez, M.G. (2007). Dynamical modeling of the electrochemical process to remove $\mathrm{Cr}(\mathrm{VI})$ from wastewaters in a tubular reactor, Journal of Chemical Technology and Biotechnology, 82, 582-587.

28. Mohanty, K., Jha, M., Meikap, B.C. \& Biswas, M.N. (2006). Biosorption of $\mathrm{Cr}(\mathrm{VI})$ from aqueous solutions by Eichhornia crassipes, Chemical Engineering Journal, 117, 71-77.

29. Murphy, V., Hughes, H. \& McLoughlin, P. (2008). Comparative Study of Chromium Biosorption by Red, Green and Brown Seaweed Biomass, Chemosphere, 70, 1128-1134.

30. Nourbakhsh, M., Sag, Y., Ozer, D., Aksu, Z., Kutsal, T. \& Caglar, A. (1994). A comparative study of various biosorbents for removal of chromium(VI) ions from industrial waste waters, Process Biochemistry, 29 (1), 1-5. 
31. Onyancha, D., Mavura, W., Ngila J. C., Ongoma, P. \& Chacha, J. (2008). Studies of chromium removal from tannery wastewaters by algae biosorbents, Spirogyra condensate and Rhizoclonium hieroglyphicum, Journal of Hazardous Materials, 158, 605-614.

32. Pehlivan E. \& Arslan G., (2007) Removal of metal ions using lignite in aqueous solution - Low cost biosorbents, Fuel Processing Technology, 88, 99-106.

33. Rengaraj, S., Yeon, K.H. \& Moon, S.H. (2001). Removal of chromium from water and wastewater by ion exchange resins, Journal of Hazardous Materials, 87, 273-287.

34. Sabour, B., Reani, A., EL Magouri, H., \& Haroun, R. (2013). Sargassum muticum (Yendo) Fensholt (Fucales, Phaeophyta) in Morocco, an invasive marine species new to the Atlantic coast of Africa, Aquatic Invasions, 8, 97-102.

35. Sari, A. \& Tuzen, M. (2008). Biosorption of total chromium from aqueous solution by red algae (Ceramium virgatum): Equilibrium, kinetic and thermodynamic studies, Journal of Hazardous Materials, 160, 349-355.

36. Sharma, A. \& Gupta, M.N. (2002). Three phase partitioning of carbohydrate polymers: separation and purification of alginates, Carbohydrate Polymers, 48, 391-395.

37. Sheng, P.X., Ting, Y.P., Chen, J.P. \& Hong, L. (2004). Sorption of lead, cooper, cadmium, zinc and nickel by marine algal biomass: characterization of biosorptive capacity and investigation of mechanisms, Journal of Colloid and Interface Science, 275, 131-141.

38. Subbaiah, M. V., Kalyani, S., Reddy, G. S., Boddu, V. M. \& Krishnaiah, A. (2008). "Biosorption of $\mathrm{Cr}(\mathrm{VI})$ from aqueous solutions using Trametes versicolor polyporus fungi, E-Journal of Chemistry, 5, 499-510.

39. Tarley, C.R.T. \& Arruda, M.A.Z. (2004). Biosorption of heavy metals using rice milling by-products. Characterisation and application for removal of metals from aqueous effluents, Chemosphere, 54, 987-995.

40. Temkin, M. I. (1941). Adsorption equilibrium and kinetics of processes on non-homogeneous surfaces and the interaction between adsorbed molecules, Journal of Physical Chemistry, 15, 296-332.

41. Ucun, H., Bayhan, Y. K., Kaya, Y., Cakici, A. \& Algur, O. F. (2002). Biosorption of chromium (VI) from aqueous solution by cone biomass of Pinus sylvestris, Bioresource Technology, 85 (2), 155158.

42. Vijayaraghavan, V. \& Yun, Y.S. (2008). Bacterial biosorbent and biosorption, Biotechnology Advances, 26, 266-291. 
43. Wang, S., Ma, Q. \& Zhu, Z.H. (2008). Characteristics of coal fly ash and adsorption application, Fuel, 87, 3469-3473.

44. Wang, X. S. \& Qin, Y. (2005). Equilibrium sorption isotherms for of $\mathrm{Cu} 2+$ on rice bran, Process Biochemistry, 40 (2), 677-680.

45. Weber, T.W. (1974). Chakraborti RK. Pore and solid diffusion models for fixed bed adsorbents, AIChE Journal, 20, 228-38.

46. World Health Organization. (2004). Guidelines for Drinking-water Quality. $3^{\text {rd }}$ ed., WHO, Geneva, vol. 1, 515 pp.

47. Yang, L. \& Chen, J.P. (2008). Biosorption of hexavalent chromium onto raw and chemically modified Sargassum sp., Bioresource Technology, 99, 297-307

48. Yun, Y. S., Park, D., Park, J.M. \& Volesky, B. (2001). Biosorption of trivalent chromium on the brown seaweed biomass, Environmental Science and Technology, 35, 4353-4358.

49. Zhang, H., Tang, Y., Cai, D., Liu, X., Wang, X., Huang, Q. \& Yu, Z. (2010). Hexavalent chromium removal from aqueous solution by algal bloom residue derived activated carbon: equilibrium and kinetic studies, Journal of Hazardous Materials, 181, 801-808. 